\title{
Effect of renal denervation on glucose metabolism after a 12 month follow-up
}

\author{
Daniel Matous ${ }^{\mathrm{a}}$, Otakar Jiravsky ${ }^{\mathrm{a}}$, Igor Nykla ${ }^{\mathrm{a}}$, Marian Branny ${ }^{\mathrm{a}}$
}

\begin{abstract}
Background. Renal denervation is an invasive endovascular procedure using radiofrequency ablation of the renal arteries. This reduces renal sympathetic activity. However, the effect of renal denervation on glucose metabolism remains unclear.
\end{abstract}

Aim. To evaluate the relation between sympathetic activity and glucose metabolism.

Methods. We enrolled 51 patients with resistant hypertension who underwent renal denervation in our hospital from September 2011 to July 2013. We divided the patients into 4 subgroups: those with diabetes mellitus; those without diabetes mellitus; patients who had undergone bilateral denervation with at least 4 radiofrequency applications to each renal artery. The last subgroup of patients had fewer than 4 applications bilaterally or only unilateral application for anatomical or technical reasons. For all patients the Simplicity flex catheter (Medtronic) was used. Fasting glucose, glycated hemoglobin, albuminuria and C-peptide were measured before the procedure and after 12 months.

Results. In all patients $(\mathrm{n}=51$ ) fasting glucose levels significantly increased (from $7.4 \pm 2.0 \mathrm{mmol} / \mathrm{L}$ to $7.8 \pm 2.6 \mathrm{mmol} / \mathrm{L}$; $P=0.032$ ). Glycated hemoglobin increased slightly but not significantly (from $46.1 \pm 10.5 \mathrm{mmol} / \mathrm{mol}$ to $47.6 \pm 13.6 \mathrm{mmol} /$ mol; $P=0.079)$. There were no significant changes in albuminuria $(71.2 \pm 191.0 \mathrm{mg} / \mathrm{L}$ to $66.1 \pm 185.5 \mathrm{mg} / \mathrm{L} ; P=0.108)$ or C-peptide levels (1178 $\pm 429 \mathrm{pmol} / \mathrm{L}$ to $1271 \pm 565 \mathrm{pmol} / \mathrm{L} ; P=0.098)$.

Conclusions. We found no effect of renal denervation on glucose metabolism after 12 months follow-up.

Key words: renal denervation, glucose metabolism, diabetes mellitus, sympathetic activity, compliance

Received: December 17, 2014; Accepted with revision: May 28, 2015; Available online: June 11, 2015 http://dx.doi.org/10.5507/bp.2015.030

${ }^{a}$ AGEL Research and Training Institue - Trinec Branch, Cardiovascular Centre, Podlesi Hospital, Trinec, Czech Republic Corresponding author:Daniel Matous, e-mail:daniel.matous@email.cz

\section{INTRODUCTION}

The vegetative nervous system plays an important role in the regulation of glucose metabolism.

Increased sympathetic activity causes hyperinsulinemia via $\beta 1$ and $\beta 2$ receptors, insulin resistance and hyperglycemia ${ }^{1}$. Insulin resistance affects glucose metabolism, is located in peripheral tissues, is limited to nonoxidative pathways of intracellular glucose disposal, and directly correlates with the severity of the hypertension ${ }^{2}$. There is a bidirectional relationship between sympathetic overactivity inducing insulin resistance and hyperinsulinemia producing sympathetic activation, thus initiating a vicious cycle ${ }^{3}$. Activation of the sympathetic nervous system contributes to insulin resistance ${ }^{4}$ and the metabolic syndrome ${ }^{5}$ and is associated with central obesity ${ }^{6}$ and risk of developing diabetes mellitus ${ }^{7}$. It has been confirmed that physiological hyperinsulinemia increases norepinephrine release from the forearm muscle in the normal human. Moreover, this response is more pronounced in patients with essential hypertension ${ }^{8}$. Although insulin itself exhibits sympathoexcitatory effects ${ }^{9,10}$, renal denervation allows us to determine the direct role of the sympathetic nervous system, without necessitating further systemic pharmacological interactions in mediating insulin resistance and its consequences. Selective denervation of renal sympathetic nerves has the potential to improve glucose metabolism and blood pressure control concurrently in patients with resistant hypertension in the absence of significant changes in body weight and alterations in lifestyle or antihypertensive medication ${ }^{11}$. Percutaneous renal denervation may represent the first nonpharmaceutical approach for treating insulin resistance and drug-resistant hypertension.

\section{METHODS}

We enrolled 51 patients with resistant hypertension who had undergone renal denervation in Podlesi Hospital Trinec, Czech Republic from September 2011 to July 2013 (Table 1). Table 1 shows the baseline characteristics. The majority of patients were male $(n=31,61 \%) ; 25(49 \%)$ patients had diabetes mellitus type 2 . The diagnosis was confirmed as recommended by the American Diabetes Association $^{12}$. The remainig 26 (51\%) patients had no diabetes; 43 (84\%) had undergone bilateral denervation with at least 4 applications of radiofrequency to each renal artery. The remaining $8(16 \%)$ patients had fewer than 4 or unilateral applications for anatomical or technical reasons. Mean age was $59.7 \pm 11.4$ years. On average, all patients $(n=51)$ were taking $5.4 \pm 1.8$ antihypertensive drugs, with $36(71 \%)$ receiving an angiotensin-converting enzyme inhibitor; 23 (45\%) on an angiotensin II receptor blocker; 50 (98\%) on diuretics; 35 (75\%) taking $\beta$-blockers; 38 (76\%) on calcium channel blockers; 29 (56\%) receiving centrally acting sympatholytic agents and 18 (36\%) taking aldosterone antagonists. One patient did not receive any 
diuretic due to intolerance. On average, all patients were taking $1.25 \pm 0.45$ peroral antidiabetic medication. Insulin therapy was taken by 3 patients and peroral antidiabetics with insulin simultaneously was taken by 4 patients. Antidiabetic treatment (insulin, peroral antidiabetics or both) had changed in 4 patients during 12 month followup. Fasting glucose, glycated hemoglobin, albuminuria and C-peptide were measured before the procedure and after 12 months. The glucose values are expressed in millimols per liter, $\mathrm{HbA}_{1 \mathrm{c}}$ millimol per mol, albuminuria milligrams per liter and $\mathrm{C}$ peptide as pikomols per liter. For statistical comparison, the two-tailed Student $t$-test were used and $P<0.05$ was regarded as significant. Data are presented as means \pm standard error of the mean. All statistical analyses were performed with Microsoft Excell statistical software.

\section{RESULTS}

In all patients $(n=51)$ fasting glucose level significantly increased (from $7.4 \pm 2.0 \mathrm{mmol} / \mathrm{L}$ to $7.8 \pm 2.6 \mathrm{mmol} / \mathrm{L} ; P=$ 0.032; Fig. 1A). Glycated hemoglobin increased nonsignificantly (from $46.1 \pm 10.5 \mathrm{mmol} / \mathrm{mol}$ to $47.6 \pm 13.6 \mathrm{mmol} /$ mol; $P=0.079$; Fig. 1B). There were no significant chang- es in albuminuria $(71.2 \pm 191.0 \mathrm{mg} / \mathrm{L}$ to $66.1 \pm 185.5 \mathrm{mg} / \mathrm{L}$; $P=0.108$; Fig. 1C) or C-peptide level (1178 $\pm 429 \mathrm{pmol} / \mathrm{L}$ to $1271 \pm 565 \mathrm{pmol} / \mathrm{L} ; P=0.098$; Fig. $1 \mathrm{D})$.

In patients with diabetes mellitus type $2(n=25 ; 49 \%)$ fasting glucose significantly increased (from 8.6 \pm 1.9 $\mathrm{mmol} / \mathrm{L}$ to $9.5 \pm 2.7 \mathrm{mmol} / \mathrm{L} ; P=0.033$ ). We found no significant changes in glycated hemoglobin levels (from $53.0 \pm 10.2 \mathrm{mmol} / \mathrm{mol}$ to $55.8 \pm 14.8 \mathrm{mmol} / \mathrm{mol} ; P=0.116)$, albuminuria (from $81.6 \pm 55.2 \mathrm{mg} / \mathrm{L}$ to $62.0 \pm 154.0 \mathrm{mg} / \mathrm{L}$; $P=0.19$ ) or C-peptide level (from $1236 \pm 463 \mathrm{pmol} / \mathrm{L}$ to $1421 \pm 686 \mathrm{pmol} / \mathrm{L} ; P=0.071$ ); (Table 2).

In patients without diabetes mellitus $(n=26 ; 51 \%)$ there were no statististicaly significant changes in any parameter. Fasting glucose (from $6.0 \pm 0.7 \mathrm{mmol} / \mathrm{L}$ to $6.1 \pm 0.8$ $\mathrm{mmol} / \mathrm{L} ; P=0.38$ ), glycated hemoglobin (from $38.9 \pm 4.1$ $\mathrm{mmol} / \mathrm{mol}$ to $39.4 \pm 4.6 \mathrm{mmol} / \mathrm{mol} ; P=0.171$ ), albuminuria (from $60.7 \pm 225.2 \mathrm{mg} / \mathrm{L}$ to $70.0 \pm 213.7 \mathrm{mg} / \mathrm{L} ; P=0.157$ ) and C-peptide (from $1116 \pm 390 \mathrm{pmol} / \mathrm{L}$ to $1128 \pm 380$ pmol/L; $P=0.441$ ); (Table 3).

In patients with bilateral denervation and at least 4 radiofrequency applications to each renal artery $(n=43$; $84 \%$ ) fasting glucose significantly increased (from $7.5 \pm 2.1$ $\mathrm{mmol} / \mathrm{L}$ to $8.1 \pm 2.8 \mathrm{mmol} / \mathrm{L} ; P=0.019)$. Glycated hemoglobin (from $46.6+/-10.7 \mathrm{mmol} / \mathrm{mol}$ to $48.5 \pm 14.3 \mathrm{mmol}$ / mol; $P=0.065$ ) and albuminuria (from $69.8 \pm 198.8 \mathrm{mg} / \mathrm{L}$

Table 1. Baseline patient characteristics, $n=51$.

\begin{tabular}{lc}
\hline Age, $\mathrm{y}$ & $59.7 \pm 11.4$ \\
Sex (male), $\mathrm{n}(\%)$ & $31(60.7)$ \\
Type 2 diabetes mellitus, $\mathrm{n}(\%)$ & $25(49)$ \\
Bilateral denervation with at least 4 applications, $\mathrm{n}(\%)$ & $43(84)$ \\
Antihypertensive drugs & $5.4 \pm 1.8$ \\
Peroral antidiabetics, $\mathrm{n}$ & $1.25 \pm 0.45$ \\
Patients on insulin, $\mathrm{n}(\%)$ & $4(8)$ \\
\hline
\end{tabular}

Table 2. Changes in glucose metabolism at 12 months in diabetes subgroup, $n=25$ (49\%).

\begin{tabular}{lccc}
\hline & Before & After & $P$ \\
\hline Fasting glucose, mmol/L & $8.6 \pm 1.9$ & $9.5 \pm 2.7$ & 0.033 \\
Glycated hemoglobin, $\mathrm{mmol} / \mathrm{mol}$ & $53.0 \pm 10.2$ & $55.8 \pm 14.8$ & 0.116 \\
Albuminuria, mg/L & $81.6 \pm 55.2$ & $62.0 \pm 154.0$ & 0.19 \\
C-peptide, $\mathrm{pmol} / \mathrm{L}$ & $1236 \pm 463$ & $1421 \pm 686$ & 0.071 \\
\hline
\end{tabular}

Table 3. Changes in glucose metabolism at 12 months in non-diabetes subgroup, $\mathrm{n}=26$ ( $51 \%)$.

\begin{tabular}{lccc}
\hline & Before & After & $P$ \\
\hline Fasting glucose, mmol/L & $6.0 \pm 0.7$ & $6.1 \pm 0.8$ & 0.38 \\
Glycated hemoglobin, mmol/mol & $38.9 \pm 4.1$ & $39.4 \pm 4.6$ & 0.171 \\
Albuminuria, mg/L & $60.7 \pm 225.2$ & $70.0 \pm 213.7$ & 0.157 \\
C-peptide, pmol/L & $1116 \pm 390$ & $1128 \pm 380$ & 0.441 \\
\hline
\end{tabular}

Table 4. Changes in glucose metabolism at 12 months in bilateral denervation and at least 4 applications to each renal artery subgroup, $\mathrm{n}=43(84 \%)$.

\begin{tabular}{llcc}
\hline & Before & After & \\
\hline Fasting glucose, mmol/L & $7.5 \pm 2.1$ & $8.1 \pm 2.8$ & 0.019 \\
Glycated hemoglobin, mmol/mol & $46.6 \pm 10.7$ & $48.5 \pm 14.3$ & 0.065 \\
Albuminuria, mg/L & $69.8 \pm 198.8$ & $74.4 \pm 200.5$ & 0.097 \\
C-peptide, pmol/L & $1165 \pm 425$ & $1313 \pm 587$ & 0.013 \\
\hline
\end{tabular}


Table 5. Changes in glucose metabolism at 12 months in unilateral or „incomplete“ denervation subgroup, $\mathrm{n}=8$ ( $16 \%)$.

\begin{tabular}{lccr}
\hline & Before & After & $P$ \\
\hline Fasting glucose, mmol/L & $6.5 \pm 0.9$ & $6.3 \pm 1.2$ & 0.19 \\
Glycated hemoglobin, mmol/mol & $43.4 \pm 9.8$ & $43.0 \pm 8.5$ & 0.424 \\
Albuminuria, mg/L & $78.1 \pm 157.3$ & $19.8 \pm 24.1$ & 0.368 \\
C-peptide, pmol/L & $1244 \pm 473$ & $1029 \pm 359$ & 0.036 \\
\hline
\end{tabular}

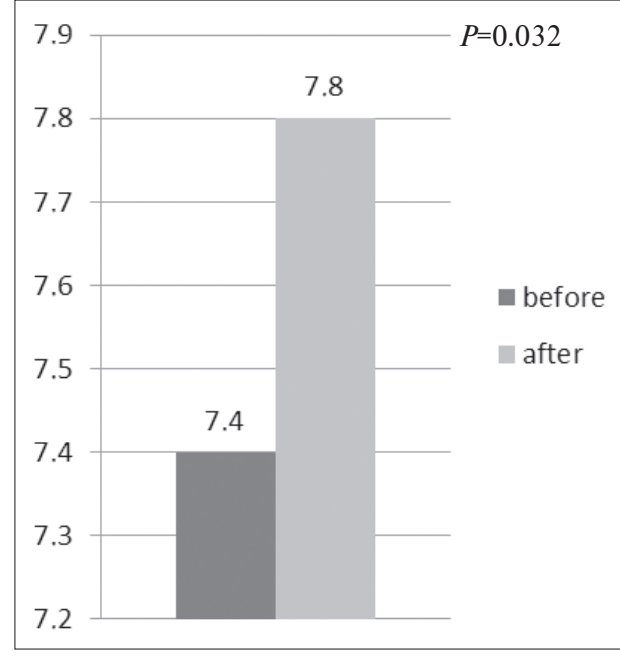

Fig. 1A. Changes in fasting glucose $(\mathrm{mmol} / \mathrm{L})$.

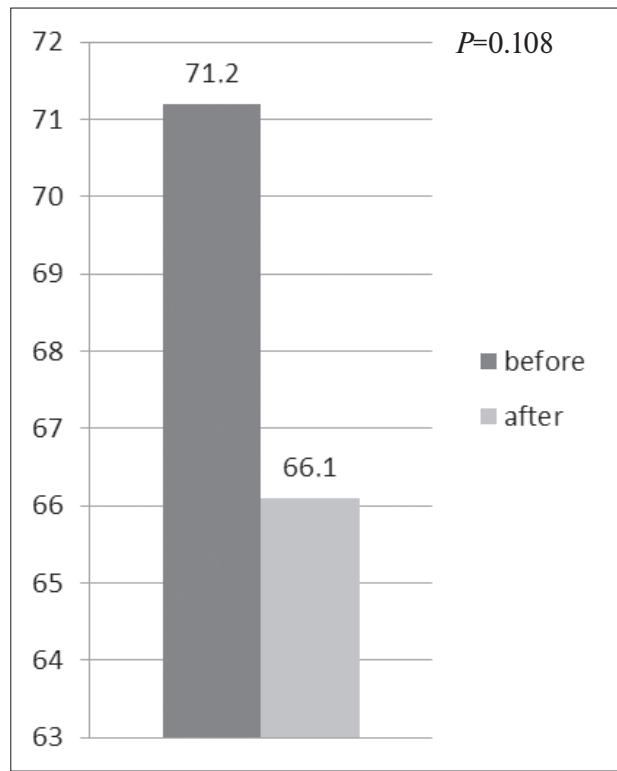

Fig. 1C. Changes in albuminuria $(\mathrm{mg} / \mathrm{L})$.

to $74.4 \pm 200.5 \mathrm{mg} / \mathrm{L} ; P=0.097)$ increased but this was not significant. C-peptide significantly increased (from $1165 \pm 425 \mathrm{pmol} / \mathrm{L}$ to $1313 \pm 587 \mathrm{pmol} / \mathrm{L} ; P=0.013)$; (Table 4).

In patients undergoing less than 4 applications or unilateral for anatomical or technical reasons $(n=8,16 \%)$ there were no significant changes in fasting glucose level (from $6.5 \pm 0.9 \mathrm{mmol} / \mathrm{L}$ to $6.3 \pm 1.2 \mathrm{mmol} / \mathrm{L} ; P=0.19$ ), glycated hemoglobin level (from $43.4 \pm 9.8 \mathrm{mmol} / \mathrm{mol}$ to $43.0 \pm 8.5 \mathrm{mmol} / \mathrm{mol} ; P=0.424$ ) and albuminuria (from

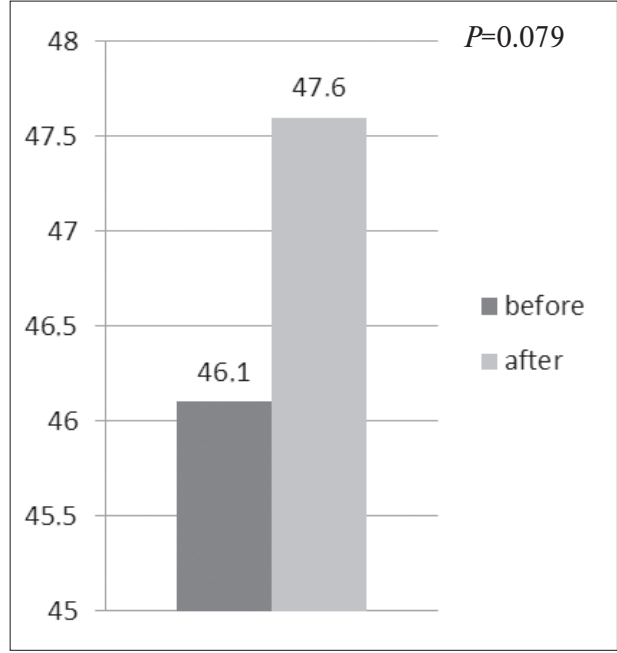

Fig. 1B. Changes in glycated hemoglobin $(\mathrm{mmol} / \mathrm{mol})$.

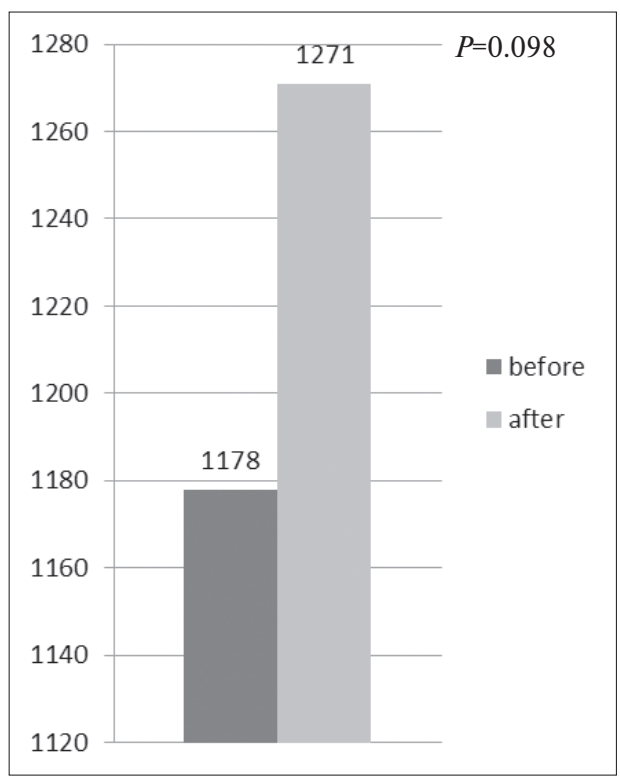

Fig. 1D. Changes in C-peptide (pmol/L).

$78.1 \pm 157.3 \mathrm{mg} / \mathrm{L}$ to $19.8 \pm 24.1 \mathrm{mg} / \mathrm{L} ; P=0.368) . \mathrm{We}$ found a significantly reduction in C-peptide level (from $1244 \pm 473 \mathrm{pmol} / \mathrm{L}$ to $1029 \pm 359 \mathrm{pmol} / \mathrm{L} ; P=0.036)$; (Table 5).

\section{DISCUSSION}

The data from Mahfoud's pilot study show that renal nerve ablation substantially improves insulin sensitivity 
and glucose metabolism, in addition to significantly reducing blood pressure. Percutaneous renal denervation may represent the first nonpharmaceutical approach for treating insulin resistance and drug-resistant hypertension ${ }^{11}$. Unfortunately, in our population of resistant hypertonics we did not confirm this effect. Our study has some limitations. A major limitation is there is no evidence that the ablation was done correctly. Direct measurement of sympathetic activity is an invasive technique appropriate to the experiment. It was very difficult to obtain the permission of patients for repeating microneurography (muscle sympathetic nerve activity measurement). For this reason, we focused on delivering the highest quality of the RDN procedure: our intervention approach involved biplanar checking of correct anterior and posterior positions. In our sample $84 \%$ patients underwent standard RDN according to common protocol - i.e. bilateral denervation with at least 4 applications of radiofrequency to each renal artery (proximal, distal, anterior, posterior - controled by biplane X-ray). Only $16 \%$ of patients underwent "incomplete" RFA. When we exclude the patients who had not had the "complete" procedure from the sample we obtained data which does not confirm the RDN influence on glucose metabolism. The others limitations may be the potential interaction with drug effects. In 4 patients we registered changes in peroral antidiabetic medication dosage or changes in dosage of insulin. A decrease in antihypertensive drugs that have been shown to influence insulin sensitivity (eg. $\beta$-blockers, diuretics, angiotensinconverting enzyme inhibitors) (ref. ${ }^{13}$ ) could also have had an impact on our results. Compliance in using medical therapy and diabetic regimen is undoubtedly also an important factor. Optimal compliance was reported in only $46 \%$ patients usings peroral antidiabetics ${ }^{14}$ and more than $50 \%$ of patients with resistant hypertension are known to be nonadherent to medications ${ }^{15}$. We found a relatively high level of non compliance to the antihypertensive medication in our patients (serum levels of antihypertensives drus). Thus, we can assume the same applies to peroral antidiabetic medication. Significant improvement in blood pressure control associated with improved compliance and adherence with therapy has been noted ${ }^{16}$. One way to improving this is to use a fixed combination of antihypertensive drugs. A 29\% significant increase in compliance or persistence with therapy is associated with the use of fixed-dose combinations of antihypertensive agents for hypertension. These findings are similar to the results of meta-analysis of the use of fixed-dose combination medications for various chronic diseases, such as diabetes mellitus, hypertension, and HIV (ref. ${ }^{17}$ ). The results of the Simplicity-3 trial are relevant. This first double blinded trial showed no significant reduction in systolic blood pressure in patients with resistant hypertension 6 months after renal-artery denervation compared with a sham control ${ }^{18}$. The outlook for renal denervation is hence currently unclear. Further studies are necessary.

\section{CONCLUSION}

We found no effect of renal denervation on glucose metabolism after 12 month follow-up in any subgroup.

\section{ACKNOWLEDGEMENTS}

Author contributions: DM: literature search; DM, OJ: manuscript writing; OJ, MB: study design; DM, OJ, IN: data collection; DM: statistical analysis; DM: data interpretation; all authors: final revision.

Conflict of interest statement: None declared.

\section{REFERENCES}

1. Ganong WF. Review of Medical Physiology. 20th ed. New York: McGraw Hill; 2001.

2. Ferrannini E, Buzzigoli G, Bonadonna R, Giorico MA, Oleggini M, Graziadei L, Pedrinelli R, Brandi L, Bevilacqua S. Insulin resistance in essential hypertension. N Engl J Med 1987;317:350-7.

3. Mancia G, Bousquet P, Elghozi JL, Esler M, Grassi G, Julius S, Reid J, Van Zwieten PA. The sympathetic nervous system and the metabolit syndrome. J Hypertens 2007;25:909-20.

4. Masuo K, Mikami H, Ogihara T, Tuck ML. Sympathetic nerve hyperaktivity precedes hyperinsulinemia and blood pressure elevation in a young, nonobese Japanese population. Am J Hypertens 1997;10:7783.

5. Grassi G, Dell'Oro R, Quarti-Trevano F, Scopelliti F, Seravalle G, Paleari F, Gamba PL, Mancia G. Neuroadrenergic and reflex abnormalities in patients with metabolic syndrome. Diabetologia 2005;48:1359-65.

6. Grassi G, Dell'Oro R, Facchini A, Quarti Trevano F, Bolla GB, Mancia $G$. Effect of central and peripheral body fat distribution on sympathetic and baroreflex function in obese normotensives. J Hypertens 2004;22:2363-9.

7. Huggett RJ, Scott EM, Gilbey SG, Stoker JB, Mackintosh AF, Mary DA. Impact of type 2 diabetes mellitus on sympathetic neural mechanisms in hypertension. Circulation 2003;108:3097-101.

8. Lembo G, Napoli R, Capaldo B, Rendina V, laccarino G, Volpe M, Trimarco B, Sacca L. Abnormal sympathetic overactivity evoked by insulin in the skeletal muscle of patients with essential hypertension. J Clin Invest 1992;90:24-9.

9. Scherrer U, Sartori C. Insulin as a vascular and sympathoexcitatory hormone: implications for blood pressure regulation, insulin sensitivity, and cardiovascular morbidity. Circulation 1997;96:4104-13.

10. Bardgett ME, McCarthy JJ, Stocker SD. Glutamatergic receptor activation in the rostral ventrolateral medulla mediates the sympathoexcitatory response to hyperinsulinemia. Hypertension 2010;55:284-90.

11. Mahfoud F, Schlaich M, Kindermann I, et al. Effect of renal sympathetic denervation on glucose metabolism in patients with resistant hypertension: a pilot study. Circulation 2011; 123:1940-6.

12. International Expert Committee report on the role of the a1c assay in the diagnosis of diabetes. Diabetes Care 2009;32:1327-34.

13. Cooper-DeHoff RM, Pacanowski MA, Pepine CJ. Cardiovascular therapies and associated glucose homeostasis: implications across the dysglycemia continuum. J Am Coll Cardiol 2009;53:28 -34.

14. Guillausseau PJ. Influence of oral antidiabetic drugs compliance on metabolic control in type 2 diabetes. A survey in general practice. Diabetes Metab 2003;29(1):79-81.

15. Jung $O$, Gechter JL, Wunder C, et al. Resistant hypertension? Assessment of adherence by toxicological urine analysis. J Hypertens 2013;31:766-74.

16. Burnier M. Medication adherence and persistence as the cornerstone of effective antihypertensive therapy. Am J Hypertens 2006;19:11906.

17. Bangalore S, Kamalakkannan G, Parkar S, Messerli FH. Fixed-dose combinations improve medication compliance: a meta-analysis. Am J Med 2007;120:713-9. 
18. Bhatt DL, Kandzari DE, O'Neill WW, D'Agostino R, Flack JM, Katzen BT, Leon MB, Liu M, Mauri L, Negoita M, Cohen SA, Oparil S, Rocha-Singh K, Townsend RR, Bakris GL. A Controlled Trial of Renal Denervation for Resistant Hypertension. N Engl J Med 2014; 370:1393-401. 